\title{
JOHN DEWEY
}

Lectures in China, 1919-1920 


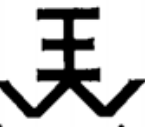

THE EAST-WEST CENTER-formally known as "The Center for Cultural and Technical Interchange Between East and West" -was established in Hawaii by the United States Congress in 1960. As a national educational institution in cooperation with the University of Hawaii, the Center's mandated goal is "to promote better relations and understanding between the United States and the nations of Asia and the Pacific through cooperative study, training, and research."

Each year about 2,000 men and women from the United States and some 40 countries and territories of Asia and the Pacific area work and study together with a multi-national East-West Center staff in wide-ranging programs dealing with problems of mutual East-West concern. Participants are supported by federal scholarships and grants, supplemented in some fields by contributions from Asian/Pacific governments and private foundations.

Center programs are conducted by the East-West Communication Institute, the East-West Culture Learning Institute, the East-West Food Institute, the East-West Population Institute, and the East-West Technology and Development Institute. Open Grants are awarded to provide scope for educational and research innovation, including a program in humanities and the arts.

East-West Center Books are published by The University Press of Hawaii to further the Center's aims and programs. 


\section{JOHN DEWEY \\ LECTURES IN CHINA, 1919-192O}

TRANSLATED FROM THE CHINESE AND EDITED BY

ROBERT W. CLOPTON / TSUIN-CHEN OU

AN EAST-WEST CENTER BOOK
THE UNIVERSITY PRESS OF HAWAII

Honolulu 
Library of Congress Catalog Card Number 72-84061 ISBN 0-8248-0212-8

Copyright (c) 1973 by The University Press of Hawaii All rights reserved Manufactured in the United States of America Designed by Eileen Cufley Williams 